\title{
Improvement of the Production Quality of the Textile Industries in Madagascar by the Knowledge Engineering
}

\author{
Andriamananarivo Ignace Rakotozandry ${ }^{1}$, Prosper Bernard ${ }^{2}$, Michel Plaisent ${ }^{3}$, Diamondra \\ Razaivaovololoniaina ${ }^{4}$
}

${ }^{1}$ Project Engineering, University of Antananarivo, Madagascar, ignacekool@yahoo.fr

2 Management School, University of Quebec in Montreal, Canada, prosper1941@yahoo.com

${ }^{3}$ Management School, University of Quebec in Montreal, Canada, michelsica@gmail.com

${ }_{4}^{4}$ Project Engineering, University of Antananarivo, Madagascar, ignacekool@yahoo.fr

*Correspondence: ignacekool@yahoo.fr

\begin{abstract}
The textile industry in Madagascar has a very important weight for the Malagasy economic situation. It is the sector that contributes the most to job creation as well as to export. There are two main categories of factories: free zone companies that are moving towards export and small and medium-sized units who produce for local consumption. The lack of technical competence of the majority of the employees constitutes a common block for the two factories category. The failure is related to the low employee's education level. This gap questions the competitiveness of textile enterprises in Madagascar at national and global level. Moreover, quality is one of the critical success factors that must be mastered by textile companies to be able to dominate the world of competition. This paper suggests a managerial strategy, the Knowledge management, as lever of quality production improvement. It has as objective the capitalization, enhancement and improvement of the company's knowledge while placing at the center the human resources. These are the sources of knowledge and the challenge is to formalize and share expert is know-how. Nonaka's model has been exploited to achieve knowledge transfer. MASK method is used to rationalize Nonaka's knowledge management cycle. It is recommended that textile companies in Madagascar integrate knowledge management into their management system in order to optimize production quality, productivity and stimulate innovation.
\end{abstract}

General Terms: Knowledge Management, Quality, Production.

Keywords: Knowledge, Management, Quality, Textile, Industry, Nonàka, Engineering, MASK, knitting, clothing.

\section{INTRODUCTION}

A very important economic role is played by the textile industries in Madagascar. Indeed, the sector that generates the most jobs is the textiles. More than 35,000 jobs have already been created or re-established in 2016, and according to prospective analyzes the sector should cover 200,000 jobs by 2022 [14]. $19.35 \%$ of the GDP as well as more than $30 \%$ of the total exports are created from the textile, clothing and accessory sector [15]. Among the countries of sub-Saharan Africa, Madagascar holds the first rank in terms of export of textile products to Europe and the United States [13]. Creation of a new 100-hectare textile city is currently in the making. Despite all these potentials, we can note certain thorny problems and one of the similar difficulties of all companies operating in the textile sector in Madagascar is the lack of technical skills of some employees. Most of these workers followed a few months of professional training before entering the factory and did not follow university studies. This situation calls into question competitiveness the Malagasy textile industries both nationally and internationally competitiveness. Furthermore, quality, which is one of the critical success factors, in all its dimensions, is not optimized through these clothing companies. In January 2019, a project called "Fond Malgache de Formation Professionnelle" was launched among to train employees of companies including the Textile / Clothing and Accessories sector. This article aims to improve this quality variable by using knowledge management. More specifically, we will try to highlight the influence of the implementation of a knowledge management project on quality in small and medium-sized textile production units, free industrial enterprise. Knowledge management has not yet been applied by many textile factories in Madagascar, however its positive spinoffs are numerous.

\section{MODEL AND METHODOLOGY}

\subsection{Knowledge Management}

Research let's start from the definition of some words that will intervene later:

Information: it is a set of structured data with one or more meanings.

Knowledge: According to ISO 9001, it is the set of available 


\section{Business and Management Research (IJBMR)}

Review Article | Volume 8, Issue 2 | Pages 28-33| e-ISSN: 2347-4696

information constituting a justified conviction and having a strong certainty of being true.

Competency: it is the ability to effectively perform a specific activity.

Know-how: Know-how is a subset of a person's knowledge, used to perform an action. It is often a compilation of knowledge, optimized to gain in performance (quality, time, quantity) [8].

« Knowledge management is a multidisciplinary strategic approach aimed for achieving the goal set by maximizing the company's knowledge [10] ». Knowledge is very valuable for a company because it constitutes its immaterial assets (wealth) and is a source of competitiveness. Any loss of knowledge is very dangerous for the survival of an organization, hence the importance of knowledge management. It's a way to keep sharing to develop the company's knowledge. Given that the current world of competition requires optimal intelligence organisation. The approach is based on eight successive phases forming a closed loop because it must be a continuous and permanent process [12]. These phases are composed by: identifying, preserving, valuing, transferring and updating knowledge.

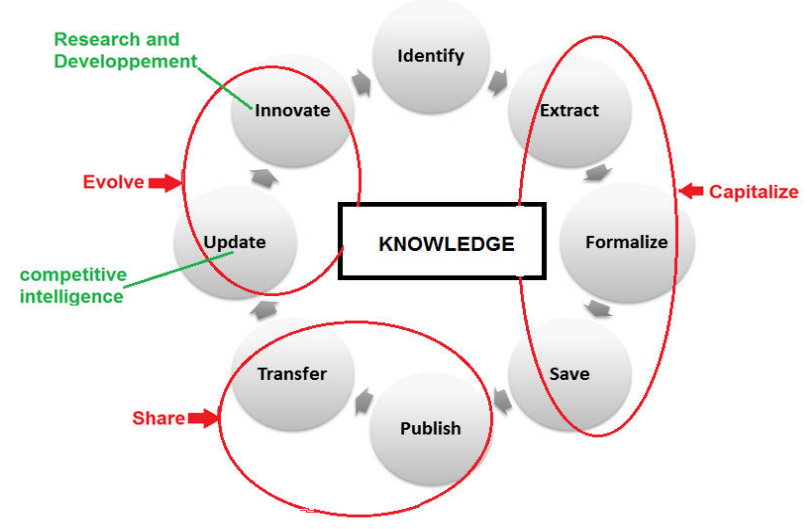

Fig. 1: the stages of knowledge management

(source: author)

Spotting: target the experts and identify the skills to be formalized while giving answers to the questions who does what? and who knows what? these skills, which are located in the subconscious of the individual holder, must be extracted. This action is complicated, as these types of knowledge are difficult to conceptualize.

Saving: After having been formalized, the knowledge must be saved and which will compose the company's "knowledge bank". Access and reuse at any time will become easy. It is at this stage that we talk about knowledge capitalization.
Publishing: This is to make available to people, or target organizations, the transcribed knowledge.

Transferring: this step is aimed at the learner acquiring the new knowledge and reusing it in order to increase or improve its abilities. This transfer can be done directly between the expert and the learner through observation and then imitate for example (training ...), or indirectly, that is to say without the intervention of the expert. Learner can use formalized knowledge beforehand.

Updating: make an information monitoring to measure the intensity and effectiveness of knowledge held in relation to news. In other words, we have to update our knowledge because it can quickly become obsolete (reactivity).

Innovating: develop new knowledge to stand out from competitors. It is the pro-activity of the company. Research and develop plays a crucial role in this phase.

\subsection{Modeling the knowledge Management}

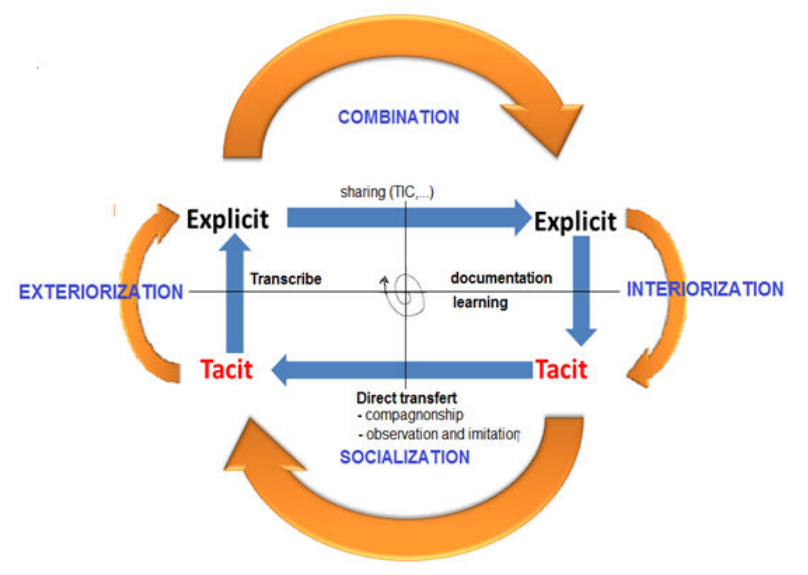

Fig.2: the knowledge management cycle according to Nonàka (source: author)

There is a multitude of knowledge management models, the best known on them are that of Nonàka, Huber, Sveiby and finally Marguerite. In this article, we will focus on the model developed by Nonàka.

According to Nonàka, the same knowledge can come in two forms:

\section{- Tacit knowledge \\ - Explicit knowledge}

The tacit knowledge is a knowledge residing in the head of an individual. Therefore, it is personal and in relation with the previous experiences lived by the individual. While explicit knowledge is a form transcribed in a formal language and having a well-defined structure of tacit knowledge. 
Nonàka defined that there are generally four modes of knowledge transmission (transfert) including Socialization, Exteriorisation, Combination and Internalization. This is the famous SECI model which is the abbreviation of the words mentioned above.

Socialization: it is the direct transfer of knowledge between the expert and the apprentice. This is the result of observation and then imitation. Of course, this is the tacit-tacit conversion.

Externalization: formalize the know-how of an individual in a memorable support (example: writing in a paper ...). This process converts tacit knowledge into explicit form. This is the challenge of knowledge management.

Combination: From explicit to explicit, it is a case of creating knowledge and learning through the sharing of explicit knowledge through meetings, exchange of information.

Interiorization: make an explicit knowledge tacit. A practical example is the formation of an individual. This can be done by documentation, reading the email, consulting a book of knowledge.

\subsection{Systemic approach of the knowledge management}

Knowledge Engineering tools make it easy to perform knowledge management tasks. Among other modeling tools such as Common Knowledge Analysis and Design System (KALAM), KALAM (Knowledge and Learning in Action Mapping) developed by Jean-Yves Prax; we will focus on the one developed by Jean-Louis Ermine, nammed MASK. This is the abbreviation for Method for Analysis and Structuring knowledge. Through this approach, knowledge will have to be analyzed according to three different angles of view: its structure, function and evolution [9]. MASK is used mainly during the explicit phase of knowledge (making tacit knowledge explicit). In addition, it facilitates the creation and transfer of knowledge in the company and contributes to the realization of the knowledge book. The implementation of MASK requires two major successive phases:

Framing stage: It is a question of determining the modeling phases that will make it possible to reach the goal of the knowledge management project that the organization has defined. In addition, the actions to be taken will have to move towards the strategic objective of the project. It is mandatory at this level to target and define the characters that will intervene in the process.

Modeling stage: it is based on the dialogue with the domain's expert in question or on the consultation of a source of information (document, database ...). The expert and this source of information constitute here the sources of knowledge and play a determining role in this step. The culmination of this phase involves the intervention of different models including the domain, activity, task, design and evolution. The following figure allows us to better identify and synthesize the successive actions of the method

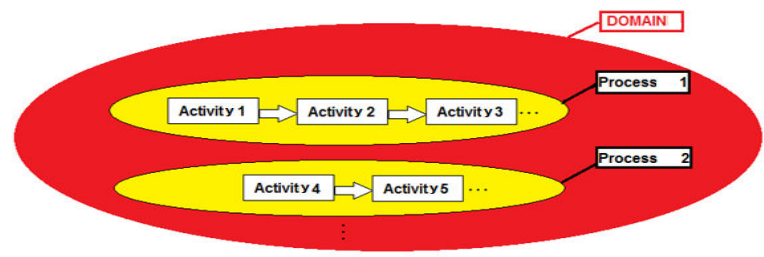

Fig.3 Modeling by MASK (source: author)

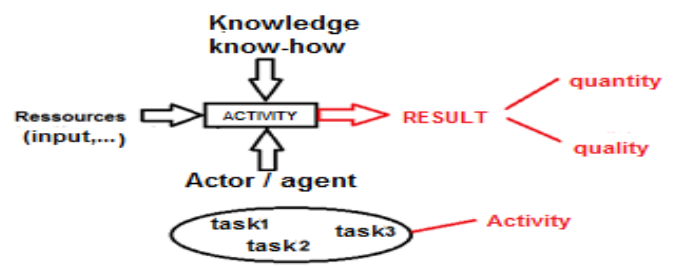

Fig.4 modeling of activities and tasks (source: author)

Table 1. Definition of actions according to the model considered (source: author)

\begin{tabular}{|c|l|}
\hline MODEL & \multicolumn{1}{|c|}{ ACTION } \\
\hline Domain & $\begin{array}{l}\text { Define and describe all the processes that make } \\
\text { up the domain }\end{array}$ \\
\hline Activity & $\begin{array}{l}\text { List / Organize / Characterize and Prioritize all } \\
\text { activities that make up each process }\end{array}$ \\
\hline Task & $\begin{array}{l}\text { Define and transcribe the know-how that } \\
\text { results in the reasoning or the actions of the } \\
\text { expert }\end{array}$ \\
\hline
\end{tabular}

Models of design and evolution reflect the dynamics of knowledge.

\subsection{Research methodology}

In order to develop the competitive position of the companies whose operate in the textile field in Madagascar, we had to understand the creation and the use of knowledge in these industries.

To do this, a factory visit in the biggest knitwear company has been established in 2018. It's about FLOREAL Madagascar, subsidiary of the Ciel textile Group; he is a major player in the textile field and international leader in knitting. He was located in Madagascar since 1990 and operating with 3 factories simultaneously. Company employees more than 1500 persons in total. Two factories are in Antananarivo, capital of Madagascar and the third in Antsirabe, a city located at $160 \mathrm{~km}$ from the capital. 
In addition, a field visit to a small production unit was made during one week in 2018. It is a small family knitting unit, located near Antsirabe's city, employing 10 people. Unit exists since twenty years. Its production capacity remains very low and insufficient for local demand. But, some of its employees have remarkable and important know-how in the field of knitting that. According to the leader of the small unit, there are at most 5 types of units like them in Madagascar. Since the others are informal and are very far from the city, it is difficult to get in touch with them. Also, its case is the same as the other rest of unity.

Interviews were conducted with a few key people from companies to gather as much information as possible about all activities. Added to this is the observation and interpretation of workstation practices. The companies also provided us some real data although some of them are confidential. The study was only limited in the field of production. Thus, the other departments were not taken into account.

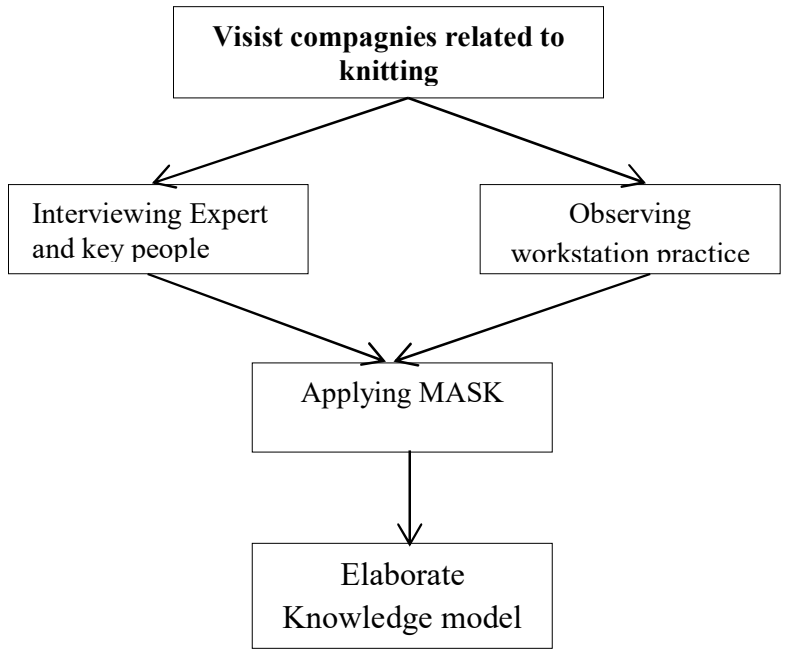

Fig.6: Research process

\section{RESULT AND DISCUSSION}

All companies studied work in the manufacture of knitwear (pullover). They are intended to be marketed outside for the free enterprise and to be consumed locally for the small production unit. In the case where the order is bulky, i.e. greater than the production capacity of the company, subcontracting is mandatory. This may sends a message of sharing and exchange know-how between the company and its subcontractor.

For Floréal, The model and all technical specifications are defined by the method company located abroad and the local company is doing only production. It can be seen that the know-how of the company's international experts in modeling may not become explicit knowledge for Floreal.
Most of actors (employees) working directly in the production did not have the opportunity to pass a college and university study. On the other hand, they can read and write. Thus, they are able to follow instructions. The workers followed professional training of a few months, on the industrial machinery (sewing, knitting...), before working in the factory. The recruitment manager requires certificates of completion and / or work certificates for some who have already worked in another factory. These situations make it possible to affirm that: the actors whose working up in the production of the company in question have very limited knowledge in the textile world.

In the knitting activity for example, some working instructions to a specific product are indicated on a paper in front of the worker and they only follows them without any concern to know the characteristics of the threads that he will use. However, these variable (torsion value, torsion mode, diameter, material type...) affect the quality of the finished product (fabric produced) knitted. According to the knitting expert: the diameter of the knitting yarn has a lot of influences on the mechanical effect (friction) during the process. Some workers do not know it yet during our investigation.

Before working independently, the workers undergo training for a few days. This is not enough to catch professionalism in the activity. The existence of a particular "knowledge book" on the work to be done will reinforce and facilitate this learning.

There are some people who worked in the factory more than 15 years. These people hold valuable tacit knowledge but have difficulty in explaining it. Maybe they are not motivated to share their assets for free.

In terms of research and development, this will subsequently stimulate innovation, the company works in partnership with a private university with a branch of study in textile engineering. For some time it begun to consider the dissertations and thesis written by students and researchers. Above are the manufacturing processes of the two companies considered: Floreal and the small unity production

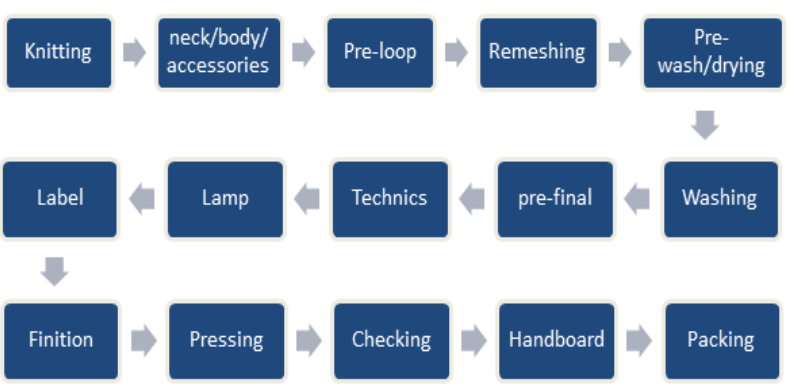

Fig.7: Production process of knitting for the free enterprise (source: company and modified by author) 


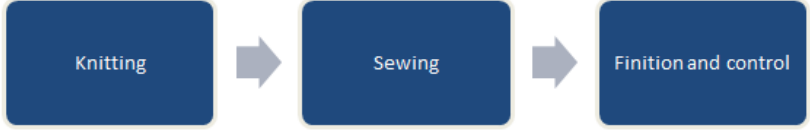

Fig.8: Knitting production process for the small enterprise unit (Source: author)

The productivity and the quality of the production of the workers are never at the same level. Those who are among the best in production have their own specific technique and method of work. For example, their movements, gestures are more elaborate and adapted. These are the know-how that must be shared (according to the Nonàka cycle) throughout the production unit to improve productivity and with a view to particularly improving the homogeneity of the quality of the finished products.

The installation of production units is ideal and facilitates internalization as well as socialization since the production process is done in a chain, so the units are located quite close to each other. This arrangement also solves a problem fairly quickly.

Applying the MASK method for the domain will result in the following results:

Only the 'knitting' activity has been taken into account for this article.

The Activity model developed will be a starting point and needs to be improved as knowledge develops in the textile industries in Madagascar. It will also allow business leaders to have an idea of what they will develop for all the activities of their organization.

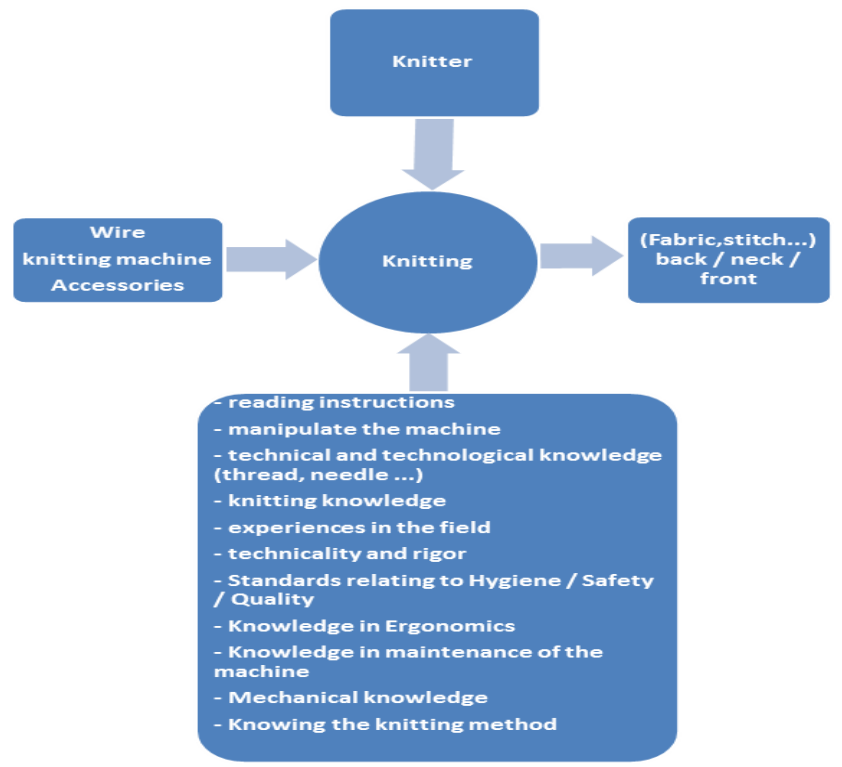

Fig.9: knitting activity model (Source: author)

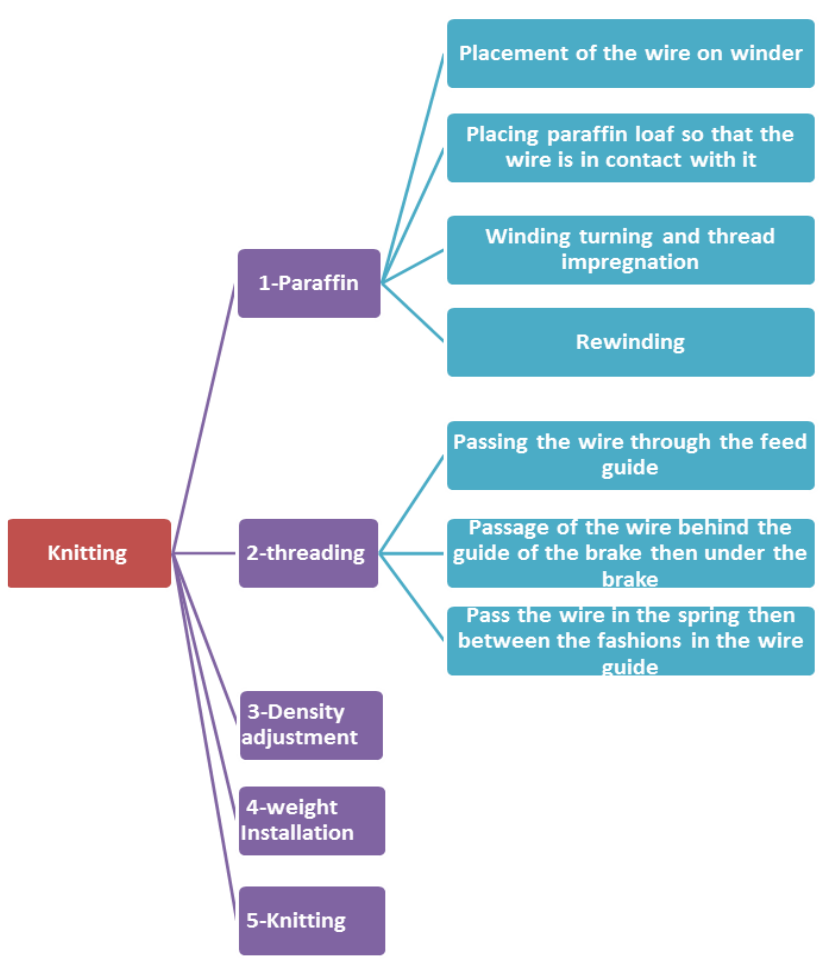

Fig. 10: Spot pattern knitting (Source: author and domain expert)

According to the experts, the density adjustment is synthesized by the following table:

Table 2. Density adjustment

\begin{tabular}{|c|c|c|}
\hline POINT & THREAD & DENSITY \\
\hline \multirow[t]{4}{*}{ Jersey } & 2 & $4 ; 5 ; 6$ \\
\hline & 3 & $6 ; 7$ \\
\hline & 4 & $7 ; 8 ; 9 ; 10$ \\
\hline & more than 4 & $10 ; 11 ; 12$ \\
\hline \multirow[t]{4}{*}{ Cotes 1/1 } & 2 & $2 ; 3$ \\
\hline & 3 & $3 ; 4 ; 5$ \\
\hline & 4 & $5 ; 6 ; 7$ \\
\hline & more than 4 & $8 ; 9 ; 10$ \\
\hline
\end{tabular}


Table 3. Types of problems and their solutions during knitting

\begin{tabular}{|l|l|}
\multicolumn{1}{|c|}{ PROBLEMS } & \multicolumn{1}{c|}{ SOLUTIONS } \\
\hline A stitch is defeated or falls from a row & $\begin{array}{l}\text { A stitch is defeated or falls from a row } \\
\text { place this mesh behind the valve and put the wire in the hook } \\
\text { reform the mesh by pulling on the heel of the needle }\end{array}$ \\
\hline several stitches were undone & open the front needle bed and use the remesher punch \\
\hline a loop appears at the beginning of the row & $\begin{array}{l}\text { check threading } \\
\text { check if the truck is moving too far }\end{array}$ \\
\hline \multirow{2}{*}{ you must unravel several ranks } & $\begin{array}{l}\text { pull the thread up and unravel the desired rows then thread } \\
\text { the last stitch kept on the hook of the needle }\end{array}$ \\
\hline the chariot hangs & $\begin{array}{l}\text { check the alignment of the bedding teeth } \\
\text { Verify the density } \\
\text { clean and oil your machine }\end{array}$ \\
\hline the weights go down too much & $\begin{array}{l}\text { make sure to mount the needles, the stitches must be under } \\
\text { the flap }\end{array}$ \\
\cline { 2 - 2 } & put the knit back and wrap it around the comb \\
\hline
\end{tabular}

Here are some common problems already experienced by specialists (knitting experts) as well as their respective solutions. These solutions have been recognized and very effective in terms of time (faster). This table is extracted from the expertise of internal agents and deserves to be taken into account by companies operating in the textile industry where knitting is among its activities. It now constitutes an explicit knowledge that organizations need to internalize and combine at the same time.

\section{CONCLUSION}

The study has allowed us to state that the textile industries in Madagascar are still weak at the organizational level. This failure does not allow them to have the best place on the competition world. One of the main causes of this blunder is the imperfection in terms of knowledge management or its non-existence in companies. Leaders lack the initiative to manage knowledge in their organization and don't realize how important it is relation to the quality of production and productivity. Indeed, as for the other domains, the benefits that knowledge management can generate for the textile industries in Madagascar are numerous in this case the improvement of the quality, the increase of the productivity, the reduction of the errors and promotion of innovation. In short, the integration of knowledge management into the quality approach is one of the levers for developing the competitiveness of textile industries in Madagascar. The results are not exhaustive and should be supplemented by other research.
[1] Agnieszka A. Szpitter, "La gestion des connaissances dans le processus d'innovation de produit," May 2014

[2] Astrid Jaime, Dominique Vinck , Mickaël Gardoni "From quality management to Knowledge Management at research organizations," Article in International Journal of Innovation Management · June 2006.

[3] Basil G. Englis, Michael R. Solomon, Paula D. Harveston, Jennifer Davey, Marla Goldsmith “ Knowledge Management as Competitive Advantage in the Textile and Apparel Value Chain," May 2014.

[4] Cherifi Ahmed, Mickaël Gardoni , Patrick Gerard Mbassegue, "Les projets de gestion de connaissances en milieu organisationnel : les défis liés à la mesure des retombées et l'énoncé des déterminants d'un cadre approprié," Conference Paper · October 2015

[5] Emmanuel Caillaud, Mickaël Gardoni, R. Houssin "Knowledge Management for Innovative Design," Conference Paper · April 2010.

[6] J-L Ermine, "MKSM Méthode pour la gestion des connaissances," AFCET-Hermès, 1996.

[7] J-L Ermine,"Ressources humaines et gestion des connaissances," ANDCP, 2001.

[8] Jean-Louis Ermine, “ A Knowledge Value Chain for Knowledge Management," Journal of Knowledge \& Communication Management, Volume 3 Number 2 pp. 85-101, October 2013.

[9] J-L Ermine," From MASK Knowledge Management Methodology to Learning Activities Described with IMS - LD," April, 2005.

[10] J-M Laurent "KM : Knowledge Management, Les trois dimensions d'un projet OCSIMA," 2005.

[11] Leoncio J. Candia," Gestion des connaissances imparfaites dans les organisations industrielles : cas d'une industrie manufacturière en Amérique Latine," Fev 2005.

[12] Michel Grunsdstein,“ Three Postulates That Change Knowledge Management Paradigm,",february 2012.

[13] Mirana Ihariliva, "Industrie textile: Une bonne performance pour madagascar", L'express de Madagascar,Dec 08,2018

[14] Randrianarivony Dominique: "le textile malgache : des atouts en trame de fond, du fil à retordre pour les concurrents", rapport EDBM, August 2017

[15] Riana R., Presse les Nouvelles,Nov 5, 2019

[16] Rakotobe Harilalaina, "Industrie du vêtement - Les opérateurs accueillent le « Textile city ", , L'express de Madagascar,March 05,2019 .

[17] S. Duizabo , N. Guillaume, "Les problématiques de gestion des connaissances dans les entreprises," Février 1997.

[18] Wali ur Rehman, “ Knowledge Creation (SECI) through Human Resource Practices and Rapport: A conceptual Model from Social P erspective," November 2013.

\section{REFERENCES}

